Secondary school pupils' preferences for different types of structured grouping practices

Susan Hallam and Judith Ireson, Institute of Education, University of London

Contact: Professor Susan Hallam, Institute of Education, University of London, 20 Bedford Way, London WC1H OAL

Phone 02076126371

Fax 02076126766

E-mail s.hallam@ioe.ac.uk or shallam@globalnet.co.uk 


\title{
Secondary school pupils' preferences for different types of structured grouping practices
}

\begin{abstract}
The aim of this paper is to explore pupils' preferences for particular types of grouping practices an area neglected in earlier research focusing on the personal and social outcomes of ability grouping. The sample comprised over 5,000 year 9 pupils (aged 13-14 years) in 45 mixed secondary comprehensive schools in England. The schools represented three levels of ability grouping in the lower school (years 7 to 9). Pupils responded to a questionnaire which explored the types of grouping that they preferred and the reasons for their choices. The majority of pupils preferred setting, although this was mediated by their set placement, type of school, socio-economic status and gender. The key reason given for this preference was that it enabled work to be matched to learning needs. The paper considers whether there are other ways of achieving this avoiding the negative social and personal outcomes of setting for some pupils.
\end{abstract}




\section{Secondary school pupils' preferences for different types of structured grouping practices}

\section{Introduction}

There has been a great deal of research internationally on the effects of structured ability grouping on the academic, personal and social outcomes for pupils. Research has highlighted that structured ability grouping can lead to low expectations, limited opportunities, and the labelling and stigmatisation of those perceived to be of low ability with consequent negative attitudes towards school. Highly structured ability grouping can also affect the makeup of particular classes with possible consequences for friendships and social interactions within those classes (see Hallam, 2002; Ireson and Hallam, 2001; Sukhnandan and Lee, 1998; Harlen and Malcolm, 1997 for reviews).

Much of the evidence suggests that highly structured ability grouping influences the expectations of pupils, teachers and parents regarding pupil prospects (Gamoran, 1986; Kerckhoff, 1986). Early research, when streaming and selective schooling were commonplace in the UK, showed that those in high streams received more encouragement to stay on at school (Hargreaves, 1967; Lacey, 1970). Gamoran and Berends (1987) argued that placing pupils in particular groups led to differential expectations regardless of actual performance or potential. However, not all of the evidence supports this view. The National Child Development Study showed no differences between streamed and non-streamed schools in their pupils' self-ratings, motivation, or plans for the future (Essen, et al., 1978; Fogelman, 1983). Nevertheless, high and low track students in the USA have been found to view the top tracks as offering a better education and more prestige (Rosenbaum, 1976). 
Streaming also engendered anti-school attitudes and alienation from school. Where whole peer groups felt alienated anti-school cultures developed. Streaming played a major role in polarizing students attitudes into pro- and anti-school camps (Hargreaves, 1967; Lacey, 1970; Ball, 1981; Abraham, 1989). High ability pupils in high streams tended to accept the school's demands as the normative definition of behaviour, whereas low stream students resisted the school's rules and attempted to subvert them. Over time, streaming fostered friendship groups (Hallinan \& Sorensen, 1985; Hallinan \& Williams, 1989), which contributed to polarized stream related attitudes, the high stream pupils tending to be more enthusiastic, those in the low streams more alienated (Oakes, Gamoran and Page, 1991).

Mixed-ability teaching has been proposed as a solution to these problems leading to greater social cohesion in the classroom. For instance, in mixed ability classes, pupils may help each other and the more able may provide encouragement and support for the less able by their example (Findlay and Bryan, 1975; Reid et al, 1982; Eilam and Finegold, 1992), although, in the USA, research has indicated that pupils enjoy lessons more when they are grouped with others of similar ability (Kulik and Kulik, 1982). There may also be differences in the quality of peer interactions in low and high ability groups. Oakes $(1982 ; 1985)$ found that students in higher ability groups reported behaviour between peers which was more supportive when compared with lower ability classes where pupils' interactions were often characterised by hostility and anger. Behaviour is often more disruptive in the lower sets (Oakes, 1982; Findley and Bryan, 1975; Berends, 1995), whereas, in mixed ability classes, the evidence suggests that lower ability pupils tend to behave better (Slavin and Karweit, 1985).

Friendships tend to be made based on the classes that pupils are in (Newbold, 1977; Ball, 1981; Hargreaves, 1967; Lacey, 1970; Rosenbaum, 1976; Schwartz, 1981). Newbold (1977) found 
that children tended to make friendships with those of similar ability although this was less marked in mixed ability forms. Whether these friendships lasted in the long term is not known. There was also a tendency for pupils to chose friends from their own social class with home, geography and primary school of origin being important factors. One of the concerns about the practice of increasing setting as pupils move through secondary school is that reorganisation into sets may split friendship groups and deprive pupils of peer support for their learning.

The research considered above was either undertaken in the USA in relation to tracking or, in the UK at a time when streaming rather than setting predominated. Since setting replaced streaming as the most common form of ability grouping at secondary level in the UK, several studies have shown that it can lead to negative attitudes of those in the lower sets and the greater possibility of them regarding themselves as socially segregated with the humiliation which this implies (Chaplain, 1996; Taylor, 1993; Ireson and Hallam, 2005). Exploring students' experiences of setting and mixed ability teaching through the observation of mathematics classes and interviews with students, Boaler (1997a; 1997b; 1997c; Boaler et al., 2000) outlined how many of the students in the schools where setting was adopted faced negative consequences as a result. Eighty three percent of the students interviewed in the setted classes wanted either to return to mixed ability teaching or to change set. This dissatisfaction was not restricted to those in the lower sets. Some of the students taught in the highest sets (Boaler 1997b) felt disadvantaged because they found it difficult to cope with the fast pace of the lessons and the pressures of consistently working at a high level which precluded them developing a deep understanding of what they were learning. They disliked the competitiveness and high expectations which they found anxiety provoking. Other students, in contrast, found the pace too slow and the competition and high expectations motivating. For 
those in the lower ability groups, setting limited expectations and set very real limits on examination entry and possible attainment (Boaler et al., 2000).

The research reported here explored pupils' experiences of ability grouping across 45 schools adopting either mixed ability, high levels of structured ability grouping, or a combination of mixed or structured groupings. It is part of a larger scale study considering the academic, personal and social outcomes of different kinds of ability grouping on pupils in Year 9 and Year 11. This paper reports findings relating to Year 9 pupils' preferences for different types of grouping and their perceptions of the advantages and disadvantages of setting and mixed ability groupings.

\section{Method}

\section{The school sample}

A stratified sample of 45 mixed gender secondary comprehensive schools was selected for the study representing a range of grouping practices, intake and location. A variety of locations were represented, spreading from London and the Southern counties of England to East Anglia and South Yorkshire.

The sample comprised three levels of ability grouping in the lower secondary school (Years 7 to 9), with 15 schools at each level:

'Mixed Ability Schools' predominantly mixed ability classes for all subjects, with setting in no more than two subjects in Year 9.

'Partially Set Schools' setting in no more than two subjects in Year 7, increasing to a 
maximum of 4 subjects in Year 9.

'Set Schools'

streaming, banding or setting in at least four subjects from Year 7.

All schools had received satisfactory inspection reports during the three years before the start of the project. Steps were taken to balance the three groups of schools in terms of their size and the social mix of their intake, using free school meals as an indicator of social disadvantage. The mixed ability schools had a slightly more socially disadvantaged intake than the set Schools. On average, the set schools were slightly smaller than the other two groups. There was good overlap across groups for both distributions.

\section{Procedures}

In each participating school all the pupils in Year 9 took part in the research. Data relating to Key Stage 2 national tests, gender, ethnic origin, attendance and whether pupils were eligible for free school meals were collected from school records. Key Stage 3 test marks in English, mathematics and science were also collected. Detailed information about the setting arrangements in year 9 was collected from interviews with school managers and from heads of department.

Pupils were asked to complete a questionnaire that included a measure of self-concept taken from the Marsh Self Description Questionnaire (SDQ II, Marsh , 1990). The SDQ II assesses three areas of academic self-concept, seven areas of non-academic self-concept and a measure of self-concept derived from the Rosenberg self-esteem scale (Rosenberg, 1979). The general self-concept scale assesses self-worth, self-confidence and self-satisfaction in general, not related to school. For the purpose of this study 4 of the sub-scales from the SDQ 
II measuring verbal, mathematics and general school self-concept and self esteem were used. In addition, a science self-concept scale using similar statements to those in the verbal and mathematics sub-scales was developed. Each sub-scale consisted of ten statements presented in Likert scale format with respondents being asked to indicate on a six point scale how true each statement was for them. A measure of attitudes towards school devised specifically for the study was included. This required pupils to respond on a five point scale to a range of statements exploring their attitudes, and those of their parents, towards school and school work, for example, School is a waste of time for me. I am very happy when I am in school. Some multiple choice questions were included in the scale, for example, this term I have got on well with: all my teachers, most of my teachers, about half of my teachers, less than half of my teachers, none of my teachers. Eight of the attitudes towards school measures were summated into a 'Liking for School' scale (see Ireson and Hallam, 2005). In relation to ability grouping pupils were asked which type of ability grouping they thought was best and were offered a choice between, mixed ability classes, sets, streams, bands, other and don't know. Pupils were then asked to explain why they thought that this was the best type of grouping. The questionnaire was completed by the pupils during lessons. Teachers or researchers assisted any pupils who had difficulties reading the questionnaire.

The level of setting in each subject varied with some schools adopting rigorous setting from year 7 while others retained mixed ability grouping or used broad ability groups. A five-point scale was constructed to indicate the amount of setting experienced by each pupil in each subject during years 7, 8 and 9. A score of 4 was given when pupils were set in years 7-9 and rigorously in year 9, a score of 3 when pupils were set in years 7-9 and broadly in year 9, a score of 2 when they were set in years 8 and 9, a score of 1 when set in year 9 only and zero where classes were entirely mixed ability. This gave an indication of each pupils' experience 
of setting. In addition, because the number of sets varied between schools, pupils were assigned to a set category: lower, middle, or upper. These categories were based on proportions of children, $25 \%$ each for the lower and upper categories and $50 \%$ for the middle. In this way set placement could be compared across schools with different year group sizes and with different setting patterns.

Responses to the open questions giving reasons for grouping preferences were analysed using an iterative process of categorisation based on a seven stage process developed by Cooper and McIntyre (1993). The process involved: 1. Reading a random sample of scripts; 2. Identifying points of similarity and difference among these transcripts in relation to the research questions; 3 . Generating theories (on the basis of 2) describing emergent answers to the research questions; 4. Testing theories against a new set of transcripts; 5. Testing new theories against transcripts already dealt with; 6. Carrying all existing theories forward to new transcripts; 7. Repeating the above process until all data were examined and all theories tested against all data. Categorisations were checked by a second judge randomly sampling from the questionnaire output. The size of the data base precluded independent categorisation of all statements.

\section{Findings}

Of those pupils who expressed a preference $62 \%$ of pupils indicated a preference for setting, $24 \%$ for mixed ability classes, and $2 \%$ each for streaming, banding or an unspecified other. $7 \%$ said that they didn't know (see Table I).

Table I about here 
Differences between school types - The proportions of preferences differed according to the type of school attended. The preference for mixed ability classes was greater where the pupils had experienced more mixed ability teaching (37\%) and was identical for those schools which had been classified as mainly adopting setting (17\%) or a mixture of setting and mixed ability classes (17\%). Setting was the preference of $71 \%$ of the pupils in set and partially set schools and $47 \%$ of the pupils in mixed ability schools (see Table I). These differences were statistically significant $\left(\mathrm{x}^{2}=407.1, \mathrm{df}=10, \mathrm{p}=.0001\right)$.

School differences - The overall trends for school type obscured very wide diversity between schools. Within the set schools the highest preference for setting was $83 \%$ and the lowest $40 \%$. In the partially set schools the range was smaller, $82 \%$ to $58 \%$. In the mixed ability schools the picture was less clear. Only three of these schools adopted mixed ability classes with no setting at all. Most had some setting, with an increase as the pupils progressed through school. In the three schools where there was no setting the pupils showed stronger preferences for mixed ability teaching with a range of $72 \%$ to $50 \%$. In the remaining mixed ability schools there was a preference for setting. The differences in responses between schools were statistically significant $\left(x^{2}=1534.1, \mathrm{df}=220, \mathrm{p}=.0001\right)$.

In some schools there was little difference in the percentage of pupils choosing setting as opposed to mixed ability with differences as small as $4 \%$. In other schools the difference was as great as $37 \%$. This suggests that in some schools there was greater cohesion within the pupil body. Pupils acknowledged that their preferences depended on their own experiences. Most, by Year 9, had experience of both setting and mixed ability classes at secondary school although this was not the case for a minority of pupils. 
Set placement differences - When the grouping preferences of those placed in high, low or middle sets for mathematics were considered, there were marked differences in the preferences of pupils for setting and mixed ability classes. Responses were received from 5276 pupils in relation to their maths set placement and their grouping preference. Of these $1520(29 \%)$ were in a top set, $2849(54 \%)$ were in a middle set and $907(17 \%)$ were in a bottom set. A greater proportion of those in the lower sets for mathematics preferred mixed ability classes when compared to those in the middle or top sets (see Table I). The order of preference for setting was reversed, with $79 \%$ of pupils in the highest sets preferring setting, $67 \%$ of those in the middle sets, and $44 \%$ of those in the lowest sets. These differences were statistically significant $\left(x^{2}=346.59, \mathrm{df}=10, \mathrm{p}=.0001\right)$. Overall, $6 \%$ indicated that they didn't know and very small proportions preferred streams, bands or other systems. The pattern was similar for science. $82 \%$ of those in the top set preferred setting. This fell to $70 \%$ for the middle sets and $54 \%$ for the bottom sets $\left(x^{2}=614.1, \mathrm{df}=15, \mathrm{p}=.0001\right)$. Of those being taught science in mixed ability classes similar proportions preferred mixed ability classes (40\%) and sets (42\%). In English, of those pupils who were setted, $83 \%$ of those in the top set preferred setting, $72 \%$ in the middle sets and $55 \%$ from the bottom sets $\left(x^{2}=\right.$ $337.7, \mathrm{df}=15, \mathrm{p}=.0001)$. Of those taught in mixed ability classes $53 \%$ reported a preference for setting and $32 \%$ for mixed ability classes (see Table I). 
Gender differences - There were gender differences in grouping preferences. Girls had a slightly greater preference for setting $(65 \%)$ than boys $(61 \%)$. Boys were more likely to prefer mixed ability classes $(26 \%)$ than girls $(21 \%)$. These differences were statistically significant, although the actual percentage difference between boys and girls was small $\left(\mathrm{x}^{2}=\right.$ 29.2, $\mathrm{df}=5, \mathrm{p}=.0001)($ see Table I).

Gender $\boldsymbol{x}$ set placement - When the data were further broken down by the sets that the pupils were in for mathematics, $79 \%$ of boys in the top sets preferred setting while $11 \%$ preferred mixed ability classes. In the middle groupings the percentage preferring setting fell to $65 \%$, and in the bottom sets to $43 \%\left(x^{2}=196.3, d f=10, p=.0001\right)$. For the girls the pattern was similar. $80 \%$ of girls in the top sets preferred setting, falling to $70 \%$ in the middle sets and $47 \%$ in the lowest sets. There were two interweaving patterns, a dominating preference for setting if pupils were in the top set alongside a slightly greater preference of girls for setting $\left(x^{2}=151.3, \mathrm{df}=10, \mathrm{p}=.0001\right)$.

Take up of free school meals - There were differences based on socio-economic status. Although there are limitations relating to the credibility of those taking free school meals as a measure of social class, they provide an indication of those who are not only eligible for free school meals but who actually take them. The data revealed that there was a greater preference for setting amongst children not taking free school meals. 64\% preferred setting and $22 \%$ mixed ability classes. For those taking free school meals, the figures were $55 \%$ and $32 \%$ respectively $\left(\mathrm{x}^{2}=27.99, \mathrm{df}=5, \mathrm{p}=.0001\right)$ (see Table I for details).

Prediction of grouping preferences - In addition to the analysis of the categorical variables outlined above, a series of independent ' $t$ ' tests were calculated to establish which variables 
might contribute to explaining preference for setting or mixed ability classes. The variables considered in this analysis were those likely to affect overall attitude to different kinds of ability grouping rather than attitudes to grouping in particular subjects. Table II sets out the means, standard deviations and analysis details of the relevant variables. These include the levels attained by pupils at Key Stage 3, a total attainment score at Key Stage 3 obtained by summing scores for mathematics, English and science, pupils' scores on the Marsh General Self-Description Scale (assessing general self-concept) and the Marsh Self-Description Scale School (assessing school self-concept), the overall level of setting experienced by the pupil, an indicator of socio-economic status, and pupils' scores on the 'Liking for School' scale (see Ireson and Hallam, 2005). There were statistically significant differences in relation to all of these variables. Those who had experienced higher levels of setting in the past preferred it to mixed ability teaching. Pupils with higher attainment levels, and higher socio-economic status preferred setting. However, the children who preferred mixed ability teaching liked school better and had higher levels of self-concept and self-esteem, although these differences were small. These findings support those exploring the relationships between ability grouping practices in schools and pupils' self-concepts (Ireson et al., 2001) and 'Liking for School' with the same sample (Ireson and Hallam, 2005).

\section{Table II about here}

A discriminant analysis was undertaken entering in a stepwise manner the variables in Table II, school type, school, set placements for mathematics, English and science, gender and take up of free school meals. The analysis was weighted to take account of the difference in size of the two groups, those preferring setting and those preferring mixed ability classes. Seven variables best discriminated between preferences for mixed ability and setted classes. 
The standardized canonical discriminant coefficients for these variables are set out in Table III. The findings are highly significant statistically $(\mathrm{p}=.0001)$ and indicate that the strongest discriminators between preference for mixed ability or setted classes are attainment as represented by Key Stage 3 national test performance and the level of ability grouping adopted in the school. Current and previous experience of ability grouping were also important predictors.

\section{Table III about here}

The group centroids were -.78 for preference for mixed ability classes and .19 for preference for setted classes. The overall canonical correlation was .36 revealing moderate relationships between the discriminant function and the included variables. The pooled within groups correlations above .2 between discriminating variables and canonical discriminating functions are set out in Table IV. They show high correlations with attainment as represented by Key Stage 3 tests, moderate correlations with variables related to set placement, and lower correlations with variables related to self-concept, liking for school and socio-economic status.

\section{Table IV about here}

Taken together the evidence from the discriminant analysis and the pooled within groups correlations suggests that pupils' overall level of attainment and their consequent set placement were the most important determinants of grouping preference. These were closely linked to their prior experiences of grouping which in turn were related to the type of school they attended. There were also links with socio- economic status, whether they took free school meals and their liking for school. Gender was not a strong predictor. The trends for male and female were similar. The percentage of predicted correct classifications of 
preference for setting or mixed ability groupings overall was $78 \%$. The level of accuracy in relation to predicting preferences for setting was $96.4 \%$ while for predicting preference for mixed ability classes it was only $18.6 \%$.

\section{Reasons for preferences for particular types of grouping}

4760 of the $8319(57 \%)$ pupils participating responded to an open question inviting them to given their reasons for preferring mixed ability or setted groupings. Table V gives details of the pupil responses relating to the advantages and disadvantages of setting and Table VI the advantages and disadvantages of mixed-ability grouping. In each table the proportions of students responding is indicated and example quotes are given. Some pupils gave responses in more than one category.

In relation to setting, $47 \%$ of students indicated that they preferred it because it enabled work to be set at an appropriate level. This was by far the largest response in any single category. 315 (5.9\%) students gave responses indicating that they didn't know. Overall, fewer comments were made in relation to the advantages and disadvantages of mixed ability teaching. The comments made most frequently related to the way that students could work together and be with friends, extend their social circle and promote equal opportunities (see Table VI).

\section{Tables V and VI about here}

\section{Discussion}

The majority of pupils reported that they preferred setting to mixed ability classes, although 
this preference was influenced by the school that they attended. Pupils in schools where mixed ability teaching was the predominant way of organising classes showed a greater preference for learning in mixed ability classes than pupils in setted or partially set schools. In schools where setting was the predominant form of grouping pupils expressed a strong preference for setting. This suggests that to some extent pupils prefer the practices with which they are familiar. However, even within schools adopting predominantly mixed-ability groupings the majority of pupils preferred setting. There were differences between pupils at different levels of attainment - pupils in low sets and those who did not attain high scores in their national tests at Key stage 3 were more likely to prefer mixed ability groupings. Overall, type of school, level of attainment and current set placement were the strongest predictors of preference. There were effects related to gender, girls tending to prefer setting, boys mixed ability classes but these were very small. Preferences clearly depended on the impact that the particular class structures had on individual pupils. Those in the bottom sets tended to prefer mixed ability groupings. This finding is hardly surprising given the evidence that being in a low set limits educational opportunities, offers a more restricted range of learning experiences and carries with it the stigmatisation of being labelled 'thick' (Boaler, 1997c; Ireson and Hallam, 2001).

The overwhelming reason given for the majority of pupils preferring setting was that it enabled teachers to match work to pupil needs. This clearly demonstrates the importance that pupils attach to their learning, putting it above social considerations, for instance, being with friends. In addition, there was an acknowledgement that setting could take into account prior attainment in different subjects which streaming and banding could not. Relatively few pupils commented on the advantages and disadvantages of mixed-ability classes. Those who did respond generally referred to social issues, friendship, co-operation, and social mixing and 
the opportunities mixed-ability classes afforded for promoting equality. The pupils' perceptions of the advantages and disadvantages of setting and mixed ability groupings reflect those of teachers (Hallam and Ireson, 2003; Ireson and Hallam, 2001). Pupils and teachers agree that setting enables the matching of work to student needs and they raise similar issues relating to the personal and social outcomes of different types of grouping and the ways that mixed ability grouping may facilitate helping and co-operative behaviour. Within schools there seems to be a shared understanding of the impact of different kinds of grouping. The issue for those managing schools is how they can provide opportunities for all pupils to maximise their potential through providing work at an appropriate level without negatively affecting the motivation and attitudes towards formal education of those with below average attainment.

There is a range of options each of which has advantages and disadvantages. Schools could adopt setting procedures and attempt to minimise their negative effects. The considerable differences between pupils' responses with regard to their grouping preferences in individual schools regardless of school type suggests that this is a possibility. School ethos seems to be able to mediate the effects of structured ability grouping. To provide a supportive ethos staff need to be sensitive to the issues, support each child in achieving his or her potential, and value what each child can attain. Schools need to ensure that an emphasis on high academic attainment is not the only achievement that is recognised. The skills of all children need to be valued. Schools might emphasise effort, good behaviour or good attendance. Non-academic work, e.g. work in the community, sporting prowess, artistic or musical achievement, or creativity can be given equal status with core academic subjects. In addition, teachers need to be constantly aware of the messages that they are giving to their pupils about what they value in their everyday interactions with pupils. Schools also need to ensure that pupils are 
appropriately allocated to groups and can move between them if their performance changes. The evidence suggests that it is not uncommon for pupils to be allocated to groups inappropriate for their learning needs (McIntyre and Ireson, 2002; Hallam and Ireson, submitted). As movement between groups is limited, once allocated to a group a pupil rarely moves out of it. Initial group placement can therefore have serious consequences for a child's life chances unless there are systems in place to facilitate re-allocation (Jackson, 1964; Neave, 1975; Barker Lunn, 1970). To overcome this problem, some schools have allowed pupils to chose the group that they are in acknowledging that grouping is based on current levels of attainment rather than 'ability'.

Another option is to adopt mixed-ability practices and ensure that learning is differentiated within the class. The evidence presented here suggests that pupils do not feel that mixed ability classes provide sufficient differentiation and that setting enables better matching of work to their needs. Certainly, teachers have been criticised for insufficiently differentiating work in the classroom, even within ability grouped classes (DES, 1992; Wragg, 1984). A further difficulty, is that teachers perceive that some subjects, which build on prior knowledge, for instance, mathematics and modern foreign languages, are particularly difficult to teach in mixed ability classes (Hallam and Ireson, 2003). To overcome these difficulties individualised learning programmes such as 'Personalised Systems of Instruction' could be adopted and operated within mixed ability classes. These have been demonstrated to be successful for older students in the USA (Waxman et al., 1985). Key for the success of programmes is that instruction is tailored to the assessed prior knowledge of each student; learners work at their own pace and receive periodic reports on their progress enabling then to plan and evaluate their own learning; and alternative materials and activities are available for cases where students do not succeed initially. While such structured programmes have not 
tended to be adopted in the UK, school based flexible learning (independent study supervised through tutorials) has been found to be a particularly successful approach to teaching GCSE geography (Hughes, 1993).

A more radical approach would be to introduce increasing modularisation of the curriculum as pupils progressed through secondary school. Pupils would work across age groups and through systems of modules in each subject area. The modules would be at different levels and progress through them would depend on completion of modules at earlier levels. Some modules in some subject areas would be compulsory, but overall pupils would have considerable choice enabling them to plan their own curriculum to include academic and vocational modules as they wished. Each module would be assessed and pupils would have a record of what they had achieved in each domain at each level. Providing that these were framed within a national assessment system, every student would be enabled to leave school with recognised qualifications and avoid the high stakes age related testing which currently puts pupils and teachers under stress and ensures that some pupils leave school at age 16 with no qualifications and negative attitudes towards formal learning which inhibit their future participation in education throughout life. Such a system would provide schools with the opportunity to give pupils more choice and to tailor a curriculum which satisfied pupils' immediate needs and long term aspirations.

\section{Acknowledgements}

We would like to thank the staff and pupils in all the participating schools for their help in this project, which was made possible by funding from the Economic and Social Research Council. 
We would also like to thank Sarah Hack and Helen Clark, the project research officers, for their assistance in collecting and entering the data.

\section{References}

Abraham, J. (1989) Testing Hargreaves' and Lacey's differentation-polarisation theory in a setted comprehensive, British Journal of Sociology, 40(1), 46-81.

Ball, S.J. (1981) Beachside Comprehensive: A case-study of secondary schooling (Cambridge, Cambridge University Press).

Barker Lunn, J.C. (1970) Streaming in the Primary School. Slough:NFER

Berends, M. (1995) Educational stratification and students' social bonding to school, British Journal of Sociology of Education, 16(3), 327-51.

Berends, M. (1995) Educational stratification and students' social bonding to school. British Journal of Sociology of Education, 16(3), 327-51.

Boaler, J. (1997a) Setting, social class and the survival of the quickest, British Educational Research Journal, 23, 575-595.

Boaler, J. (1997b) When even the winners are losers: evaluating the experiences of 'top set' students, Journal of Curriculum Studies, 29, 165-182. 
Boaler, J. (1997c) Experiencing school mathematics: teaching styles, sex and setting (Buckingham, Open University Press).

Boaler, J., Wiliam, D., \& Brown, M. (2000) Experiences of ability grouping -disaffection, polarisation and the construction of failure. British Educational Research Journal, 28(5), 6311-648.

Chaplain, R. (1996) Pupils under pressure: coping with stress at school. In J.Rudduck, Chaplain, R \& G. Wallace (eds) School Improvement: What can pupils tell us? (London, David Fulton Publishers)

Cooper, P., \& McIntyre, D. (1993) Commonality in teachers' and pupils' perceptions of effective classroom learning. British Journal of Educational Psychology, 63, 381-399.

Department for Education and Science (1992) The Education of Very Able Children in Maintained Schools: A review by HMI. London: HMSO

Eilam, B. \& Finegold, M. (1992) The heterogeneous class: a solution of just another problem?. Studies in Educational Evaluation, 18(2), 265-78.

Essen, J., Fogelman, K. \& Tibbenham, A. (1978) Some non-academic developmental correlates of ability-grouping in secondary schools, Educational Studies, 5(1), 83-93. 
Findlay, W., \& Bryan, M. (1975) The pros and cons of ability grouping. Phi Delta Kappan, 66, 12.

Fogelman, K. (1983) Ability grouping in the Secondary School In K. Fogelman (Ed) Growing up in Great Britain, Papers from the National Child Development Study, Macmillan for NCB.

Gamoran, A. (1986) Instructional and institutional effects of ability grouping, Sociology of Education, 59, 185-198.

Gamoran, A. \& Berends, M. (1987) The effects of stratification in secondary schools: Synthesis of survey and ethnographic research. Review of Educational Research, 57, 415-435.

Hallam, S. (2002) Ability Grouping in Schools: a Literature Review (Institute of Education, University of London)

Hallam, S. \& Ireson, J. (2003) Secondary School Teachers' Attitudes to and Beliefs about Ability Grouping, British Journal of Educational Psychology, 73, 343-356.

Hallam, S. \& Ireson, J. (submitted) Secondary school pupils' satisfaction with their ability group placements, British Educational Research Journal.

Hallinan, M., \& Sorensen, A. (1985) Ability grouping and student friendships. American Educational Research Journal, 22, 485-499. 
Hallinan, M., \& Williams, R. (1989) Interracial friendship choices in secondary schools. American Sociological Review, 54, 67-78.

Hargreaves, D.H. (1967) Social relations in a Secondary school, London: Tinling.

Harlen, W. \& Malcolm, H. (1997) Setting and streaming: a research review (Using Research Series 18) (Edinburgh, SCRE)

Hughes, M. (1993) Flexible Learning: Evidence Examined. Stafford: Network Educational Press Ltd.

Ireson, J. \& Hallam, S. (2001) Ability grouping in education (London, Sage)

Ireson, J., Hallam, S., \& Plewis, I. (2001) Ability grouping in secondary schools: Effects on pupils'self-concepts, British Journal of Educational Psychology, 71, 315-326.

Ireson, J., and Hallam, S. (2005) Pupils' liking for school: self concept, ability grouping and pupils' experience of teaching. British Journal of Educational Psychology, 75, 1-16.

Ireson, J., Hallam, S., \& Plewis, I. (2001) Ability grouping in secondary schools: Effects on pupils'self-concepts, British Journal of Educational Psychology, 71, 315-326.

Jackson, B. (1964) Streaming: an Education System in Miniature. London: Routledge and Kegan Paul. 
Kerckhoff, A. (1986) Effects of ability grouping in British secondary schools. American Sociological Review, 51, 842-858.

Kulik, C.-L.C., \& Kulik, J.A. (1982) effects of ability grouping on secondary school students: A meta-analysis of evaluation findings. American Educational Research Journal, 19, 415-428.

Lacey, C. (1970) Hightown Grammar (Manchester, Manchester University Press)

Marsh, H.W. (1990) Self Description Questionnaire Manual (Sydney, University of Western Sydney).

McIntyre, H, \& Ireson, I. (2002) Within-class ability grouping: placement of pupils and groups and self-concept, British Educational Research Journal, 28(2), 249-264.

Neave, G. (1975) How they fared: The impact of the comprehensive school on the university. London: Routledge and Kegan Paul

Newbold, D. (1977) Ability grouping: the Banbury Enquiry. Slough: National Foundation for Educational Research Publishing Company Ltd.

Oakes, J. (1982) The reproduction of inequity: the content of secondary school tracking, The Urban Review, 14(2), 107-120.

Oakes, J. (1985) Keeping track: How schools structure inequality. New Haven: Yale University Press. 
Oakes, J., Gamoran, A., \& Page, R. (1991) Curriculum differentiation: Opportunities, consequences and meanings. In P. Jackson (Ed) Handbook of research on curriculum. New York: Macmillan.

Reid, M.E., Clunies-Ross, L.R., Goacher, B., \& Vile, D. (1982) Mixed Ability Teaching: Problems and Possibilities. Windsor: NFER Nelson.

Rosenbaum, J.E. (1976) Making inequality: The hidden curriculum of high school tracking. New York: Wiley

Rosenberg, M. (1979) Conceiving the Self. New York: Basic Books.

Schwartz, F. (1981) Supporting or subverting learning: Peer groups patterns in four tracked schools. Anthropology and Education Quarterly, 12, 99-121.

Slavin, R.E. \& Karweit, N.L. (1985) Effects of whole class, ability grouped and individualised instruction on mathematics achievement, American Educational Research Journal, 22(3), 35167.

Sukhnandan, L., \& Lee, B. (1998) Streaming, setting and grouping by ability (Slough, National Foundation for Educational Research).

Taylor, N. (1993) Ability grouping and its effect on pupil behaviour: A case study of a Midlands comprehensive school, Education Today, 43(2), 14-17. 
Waxman, H.C., Wang, M.C., Anderson, K.A. \& Walberg, H.J. (1985) Synthesis of research on the effects of adaptive education, Educational Leadership, 43(1), 27-9.

Wragg, E.C. (ed.) (1984) Classroom teaching skills: The research findings of the teacher education project. London: Routledge. 
Table I: Preferred grouping structures 


\begin{tabular}{|c|c|c|c|c|c|c|}
\hline & $\begin{array}{l}\text { Mixed } \\
\text { ability } \\
\text { classes }\end{array}$ & Setting & Streaming & Banding & Other & $\begin{array}{l}\text { Don't } \\
\text { know }\end{array}$ \\
\hline $\begin{array}{l}\text { Total sample } \\
\text { responding to } \\
\text { statement about } \\
\text { preferences } \\
(6088)\end{array}$ & $24 \%(1450)$ & $62 \%(3797)$ & $2 \%(136)$ & $\begin{array}{l}2 \% \\
(120)\end{array}$ & $\begin{array}{l}2 \% \\
(140)\end{array}$ & $\begin{array}{l}7 \% \\
(446)\end{array}$ \\
\hline \multicolumn{7}{|c|}{ Type of school } \\
\hline $\begin{array}{l}\text { Mixed ability } \\
\text { schools } \\
(2104)\end{array}$ & $38 \%(788)$ & $47 \%(982)$ & $3 \%(53)$ & $2 \%(35)$ & $\begin{array}{l}3 \% \\
(67)\end{array}$ & $\begin{array}{l}9 \% \\
(179)\end{array}$ \\
\hline $\begin{array}{l}\text { Partially set } \\
\text { schools } \\
(1896)\end{array}$ & $17 \%(315)$ & $71 \%(1340)$ & $2 \%(32)$ & $2 \%(31)$ & $\begin{array}{l}2 \% \\
(41)\end{array}$ & $\begin{array}{l}7 \% \\
(137)\end{array}$ \\
\hline Set schools (2088) & $17 \%(347)$ & $71 \%(1474)$ & $2 \%(51)$ & $3 \%(54)$ & $\begin{array}{l}2 \% \\
(32)\end{array}$ & $\begin{array}{l}6 \% \\
(130)\end{array}$ \\
\hline \multicolumn{7}{|c|}{ Set placement by subject } \\
\hline \multicolumn{7}{|c|}{ Mathematics } \\
\hline $\begin{array}{l}\text { Mathematics top } \\
\text { sets } \\
(1519)\end{array}$ & $11 \%(160)$ & $79 \%(1198)$ & $2 \%(27)$ & $2 \%(35)$ & $\begin{array}{l}2 \% \\
(31)\end{array}$ & $5 \%(68)$ \\
\hline $\begin{array}{l}\text { Mathematics } \\
\text { middle sets } \\
(2849)\end{array}$ & $20 \%(566)$ & $67 \%(1911)$ & $2 \%(61)$ & $2 \%(57)$ & $\begin{array}{l}2 \% \\
(64)\end{array}$ & $\begin{array}{l}7 \% \\
(190)\end{array}$ \\
\hline $\begin{array}{l}\text { Mathematics } \\
\text { bottom sets } \\
(907)\end{array}$ & $38 \%(346)$ & $44 \%(402)$ & $3 \%(23)$ & $2 \%(19)$ & $\begin{array}{l}4 \% \\
(37)\end{array}$ & $9 \%(80)$ \\
\hline \multicolumn{7}{|c|}{ Science } \\
\hline $\begin{array}{l}\text { Science top sets } \\
(1225)\end{array}$ & $8 \%(94)$ & $82 \%(1009)$ & $2 \%(19)$ & $2 \%(23)$ & $\begin{array}{l}2 \% \\
(26) \\
\end{array}$ & $4 \%(54)$ \\
\hline $\begin{array}{l}\text { Science middle } \\
\text { sets (1981) }\end{array}$ & $17 \%(343)$ & $70 \%(1383)$ & $2 \%(48)$ & $2 \%(41)$ & $\begin{array}{l}2 \% \\
(30)\end{array}$ & $\begin{array}{l}7 \% \\
(136)\end{array}$ \\
\hline $\begin{array}{l}\text { Science bottom } \\
\text { sets }(702)\end{array}$ & $31 \%(128)$ & $54 \%(380)$ & $2 \%(13)$ & $3 \%(23)$ & $1 \%(9)$ & $8 \%(59)$ \\
\hline $\begin{array}{l}\text { Science mixed } \\
\text { ability classes } \\
(1460)\end{array}$ & $40 \%(580)$ & $42 \%(615)$ & $3 \%(42)$ & $2 \%(25)$ & $\begin{array}{l}4 \% \\
(62)\end{array}$ & $\begin{array}{l}9 \% \\
(136)\end{array}$ \\
\hline \multicolumn{7}{|c|}{ English } \\
\hline $\begin{array}{l}\text { English top sets } \\
(812)\end{array}$ & $7 \%(60)$ & $83 \%(670)$ & $2 \%(18)$ & $2 \%(12)$ & $\begin{array}{l}2 \% \\
(13) \\
\end{array}$ & $5 \%(39)$ \\
\hline $\begin{array}{l}\text { English middle } \\
\text { sets (1324) }\end{array}$ & $16 \%(216)$ & $72 \%(954)$ & $2 \%(26)$ & $1 \%(19)$ & $\begin{array}{l}1 \% \\
(15) \\
\end{array}$ & $7 \%(94)$ \\
\hline $\begin{array}{l}\text { English bottom } \\
\text { sets (418) }\end{array}$ & $29 \%(119)$ & $55 \%(229)$ & $2 \%(9)$ & $2 \%(10)$ & $2 \%(8)$ & $\begin{array}{l}10 \% \\
(43) \\
\end{array}$ \\
\hline $\begin{array}{l}\text { English mixed } \\
\text { ability classes } \\
(2649)\end{array}$ & $32 \%(841)$ & $53 \%(1415)$ & $2 \%(64)$ & $2 \%(44)$ & $\begin{array}{l}3 \% \\
(78)\end{array}$ & $\begin{array}{l}8 \% \\
(207)\end{array}$ \\
\hline \multicolumn{7}{|c|}{ Gender } \\
\hline
\end{tabular}




\begin{tabular}{|c|c|c|c|c|c|c|}
\hline Boys (3147) & $26 \%(826)$ & $61 \%(1922)$ & $2 \%(68)$ & $2 \%(58)$ & $\begin{array}{l}2 \% \\
(71)\end{array}$ & $\begin{array}{l}6 \% \\
(202)\end{array}$ \\
\hline Girls (2833) & $21 \%(585)$ & $65 \%(1830)$ & $2 \%(63)$ & $2 \%(60)$ & $\begin{array}{l}2 \% \\
(66)\end{array}$ & $\begin{array}{l}8 \% \\
(229)\end{array}$ \\
\hline \multicolumn{7}{|c|}{ Maths set placement by gender } \\
\hline Boys top sets (770) & $11 \%(88)$ & $79 \%(607)$ & $2 \%(14)$ & $2 \%(17)$ & $\begin{array}{l}3 \% \\
(19)\end{array}$ & $3 \%(25)$ \\
\hline $\begin{array}{l}\text { Boys middle sets } \\
(1441)\end{array}$ & $23 \%(335)$ & $65 \%(939)$ & $2 \%(33)$ & $2 \%(28)$ & $\begin{array}{l}2 \% \\
(28)\end{array}$ & $5 \%(78)$ \\
\hline $\begin{array}{l}\text { Boys bottoms sets } \\
\text { (497) }\end{array}$ & $41 \%(203)$ & $43 \%(215)$ & $2 \%(8)$ & $2 \%(8)$ & $\begin{array}{l}4 \% \\
(20)\end{array}$ & $9 \%(43)$ \\
\hline Girls top sets & $9 \%(66)$ & $79 \%(583)$ & $2 \%(13)$ & $3 \%(18)$ & $\begin{array}{l}2 \% \\
(12)\end{array}$ & $6 \%(42)$ \\
\hline Girls middle sets & $16 \%(216)$ & $70 \%(942)$ & $2 \%(28)$ & $2 \%(27)$ & $\begin{array}{l}2 \% \\
(33)\end{array}$ & $\begin{array}{l}8 \% \\
(105)\end{array}$ \\
\hline Girls bottom sets & $34 \%(133)$ & $47 \%(183)$ & $3 \%(12)$ & $3 \%(11)$ & $\begin{array}{l}4 \% \\
(17)\end{array}$ & $9 \%(35)$ \\
\hline \multicolumn{7}{|c|}{ Pupils taking free school meals } \\
\hline $\begin{array}{l}\text { Not taking free } \\
\text { schools meals }\end{array}$ & $22 \%(985)$ & $64 \%(2847)$ & $2 \%(100)$ & $2 \%(94)$ & $\begin{array}{l}2 \% \\
(107)\end{array}$ & $\begin{array}{l}7 \% \\
(293)\end{array}$ \\
\hline $\begin{array}{l}\text { Taking free school } \\
\text { meals }\end{array}$ & $32 \%(176)$ & $55 \%(304)$ & $2 \%(9)$ & $2 \%(10)$ & $\begin{array}{l}2 \% \\
(11)\end{array}$ & $7 \%(40)$ \\
\hline
\end{tabular}

* Percentages have been rounded to the nearest whole number 
Table II: Mean differences of those preferring mixed ability or setted classes

\begin{tabular}{|c|c|c|c|c|c|c|c|c|c|c|}
\hline & \multicolumn{3}{|c|}{$\begin{array}{l}\text { Preference for mixed } \\
\text { ability classes }\end{array}$} & \multicolumn{3}{|c|}{$\begin{array}{l}\text { Preference for setted } \\
\text { classes }\end{array}$} & \multicolumn{4}{|c|}{ Statistical information } \\
\hline & $\mathrm{N}$ & Mean & SD & $\mathrm{N}$ & Mean & SD & $\mathrm{T}$ & Df & Sig & Diff \\
\hline Key Stage 3 total level & 1300 & 13.99 & 3.1 & 3266 & 16.1 & 3.01 & -20.1 & 4564 & .0001 & -2.07 \\
\hline $\begin{array}{l}\text { Key Stage } 3 \text { Total test } \\
\text { score: maths + English + } \\
\text { Science }\end{array}$ & 1300 & 205.5 & 43.6 & 3268 & 228.3 & 41.5 & -16.15 & 2284.3 & .0001 & -22.8 \\
\hline $\begin{array}{l}\text { Marsh General Self- } \\
\text { Description Scale }\end{array}$ & 1535 & 47.1 & 8.6 & 3654 & 49.28 & 7.4 & -8.89 & 2533.6 & .0001 & -2.24 \\
\hline $\begin{array}{l}\text { Marsh Self-Description } \\
\text { Scale School }\end{array}$ & 1551 & 42.4 & 8.89 & 3660 & 46.1 & 7.97 & -13.89 & 2655.2 & .0001 & -3.63 \\
\hline $\begin{array}{l}\text { Type of setting experienced } \\
\text { overall by pupil }\end{array}$ & 1567 & 5.1 & 4.16 & 3679 & 7.57 & 3.78 & -20.16 & 2719.14 & .0001 & -2.46 \\
\hline $\begin{array}{l}\text { Indicator of socio- } \\
\text { economic status }\end{array}$ & 882 & 1.73 & .65 & 2446 & 1.86 & .64 & -5.23 & 3326 & .0001 & -.13 \\
\hline Liking for school scale & 1435 & 16.91 & 5.26 & 3385 & 15.84 & 4.73 & 6.7 & 2463.38 & .0001 & 1.07 \\
\hline
\end{tabular}

Low scores on the Marsh Scales and the Liking for School scale indicate more positive self-concept and greater liking for school. 
Table III: Standardized canonical discriminant coefficients

\begin{tabular}{|l|l|}
\hline Variable & Coefficient \\
\hline Key Stage 3 total level & .79 \\
\hline Set placement for science & $-.29 ;$ \\
\hline Set placement for maths & $-21 ;$ \\
\hline Total setting experience & $-.49 ;$ \\
\hline Score on the Liking for School scale & $-.25 ;$ \\
\hline Type of school & $.79 ;$ \\
\hline Gender & .14 \\
\hline
\end{tabular}


Table IV: Pooled within groups correlations between discriminating variables and canonical discriminating functions

\begin{tabular}{|l|l|}
\hline Variable & Correlation \\
\hline Key Stage 3 total level ; & .74 \\
\hline Maths set placement & -.6 \\
\hline Science set placement & -.55 \\
\hline English set placement & -.4 \\
\hline Type of school & .48 \\
\hline Total setting experienced & .408 \\
\hline Marsh self-description questionnaire general school scale & .407 \\
\hline Marsh self-description questionnaire general self scale & .3 \\
\hline Liking for School scale & -.29 \\
\hline Indicator of socio-economic status & .26 \\
\hline
\end{tabular}


Table V: Perceived advantages and disadvantages of setting 


\begin{tabular}{|c|c|}
\hline Advantages of and disadvantages of setting & $\begin{array}{l}\text { Percentage of } \\
\text { students } \\
\text { responding }\end{array}$ \\
\hline $\begin{array}{l}\text { Work is at an appropriate level } \\
\text { Sets mean that you are in the right set for your ability with people } \\
\text { who are of the same ability and doing work that meets your ability. } \\
\text { Sets are best because the people who are good in a subject get } \\
\text { pushed further and the people not so good work at a slower pace. }\end{array}$ & $47 \%(2526)$ \\
\hline $\begin{array}{l}\text { Attainment in different subjects is taken into account } \\
\text { Some people may be really good in some subjects but pretty bad at } \\
\text { others so they need to be in the right group for each subject so they } \\
\text { can understand things that they do properly. }\end{array}$ & $3.3 \%(178)$ \\
\hline $\begin{array}{l}\text { De-motivating } \\
\text { Those in the bottom sets give up. }\end{array}$ & $2.3 \%(121)$ \\
\hline $\begin{array}{l}\text { Teacher attention is equally distributed } \\
\text { In sets teachers can concentrate on all the class instead of a few } \\
\text { that need a lot of help }\end{array}$ & $1.6 \%(86)$ \\
\hline $\begin{array}{l}\text { There is more bullying and teasing } \\
\text { People get picked on because they're too clever or dumb. }\end{array}$ & $1.5 \%(80)$ \\
\hline $\begin{array}{l}\text { Repetition is avoided } \\
\text { I think that sets are best because then you can learn something new } \\
\text { every time... when you're in mixed groups you go over the easy } \\
\text { stuff over and over again. }\end{array}$ & $1.4 \%(77)$ \\
\hline $\begin{array}{l}\text { The more able are supported and challenged } \\
\text { Sets are best because the people who are good in a subject get }\end{array}$ & $2 \%(108)$ \\
\hline
\end{tabular}




\begin{tabular}{|l|l|}
\hline $\begin{array}{l}\text { pushed further and the people who are not so good work at a } \\
\text { slower pace. }\end{array}$ & \\
\hline $\begin{array}{l}\text { Sets make teaching easier } \\
\text { us. } \text { easier for the teachers. They can do the same things with all of }\end{array}$ & $1.1 \%$ (59) \\
\hline $\begin{array}{l}\text { Lower ability pupils can get the help they need } \\
\text { Teachers can help those who don't understand. }\end{array}$ & $1 \%(55)$ \\
\hline $\begin{array}{l}\text { Increased mixing in different subjects } \\
\text { You get to meet people from other classes. It's fun. }\end{array}$ & $.92 \%$ (49) \\
\hline $\begin{array}{l}\text { Increased motivation and competition } \\
\text { I like setting because I think I work well with people of good ability } \\
\text { because I compete with them which pushes me to do well. }\end{array}$ & $.78 \%$ (42) \\
\hline
\end{tabular}

Number of students responding is indicated in brackets 
Table VI: Perceived advantages and disadvantages of mixed ability teaching 


\begin{tabular}{|c|c|}
\hline & $\begin{array}{l}\text { Percentage of students } \\
\text { responding }\end{array}$ \\
\hline $\begin{array}{l}\text { Co-operation and help } \\
\text { Mixed ability is best because if the teacher is helping somebody } \\
\text { else the other students who need help can get it off students who } \\
\text { know what they're doing which saves time. }\end{array}$ & $3.5 \%(188)$ \\
\hline $\begin{array}{l}\text { Friendships } \\
\text { In mixed ability classes you can be with your friends. }\end{array}$ & $3.5 \%(187)$ \\
\hline $\begin{array}{l}\text { Encourage social mixing } \\
\text { You get to work with people different to you which helps your } \\
\text { social skills. }\end{array}$ & $2.9 \%(168)$ \\
\hline $\begin{array}{l}\text { Equality of opportunity } \\
\text { Mixed ability is the best grouping because it gives everybody } \\
\text { an equal opportunity to do well. }\end{array}$ & $2.9 \%(156)$ \\
\hline $\begin{array}{l}\text { Lower ability pupils are pushed to catch up } \\
\text { Mixed ability grouping is the best because the less clever get } \\
\text { pushed to do better. }\end{array}$ & $2.3 \%(121)$ \\
\hline $\begin{array}{l}\text { De-motivates, leaves pupils feeling left out and giving up } \\
\text { Sometimes I get left behind and I feel like giving up. }\end{array}$ & $1.2 \%(65)$ \\
\hline $\begin{array}{l}\text { Behaviour } \\
\text { If you re in mixed ability classes for English, science and maths } \\
\text { and there's a really disruptive person in the class you won't } \\
\text { learning a thing. }\end{array}$ & $1.2 \%(63)$ \\
\hline $\begin{array}{l}\text { Less able pupils get more attention } \\
\text { In mixed classes the teacher spends all the time with the ones }\end{array}$ & $.77 \%(41)$ \\
\hline
\end{tabular}




\begin{tabular}{|l|l|}
\hline who can't do it. & \\
\hline Pupils can work at their own level and pace & $.7 \%(38)$ \\
\hline Pupils interact positively in a relaxed manner & \\
We can work together and help each other. & $.45 \%(24)$ \\
There's no pressure to rush through work. & \\
\hline
\end{tabular}

Number of students responding is indicated in brackets 